\title{
STEEKPROEVEN ALS MIDDEL VAN ACCOUNTANTSCONTROLE
}

\author{
door A. van Heerden
}

\section{Inleiding}

De situatie in Nederland ten aanzien van het probleem of, en zo ja in hoeverre, steekproeven een toelaatbaar middel van accountantscontrole kan zijn is naar mijn mening nog steeds niet geheel bevredigend. Enerzijds bestaat er in de praktische beroepsuitoefening een steeds sterkere neiging tot het hanteren van steekproeven over te gaan, zulks onder druk van de kosten verbonden aan het volledig controleren van die gebieden waar detailcontrole noodzakelijk is. Anderzijds is de theorie er naar mijn gevoel nog niet in geslaagd een geheel sluitend betoog te leveren voor de toelaatbaarheid van steekproeven. De klap, toegebracht door het vermaarde artikel van Kleerekoper 1), kwam zo hard aan, dat sindsdien de steekproef door accountants met wantrouwen werd bezien en dat het bijna een kwart eeuw duurde eer in de Nederlandse vakliteratuur de verdediging van de steekproef weer ter hand werd genomen. Laat ik hier onmiddellijk aan toevoegen, dat het bovenstaande niet de bedoeling heeft iets ten nadele van dat artikel te zeggen. Integendeel, ik heb persoonlijk nog steeds de grootste bewondering voor de scherpe analyse, waarmede de toenmalige literatuur door Kleerekoper aan de kaak werd gesteld en ik heb het gevoel dat veel van wat thans aan literatuur over dit onderwerp beschikbaar is, ware het vóór 1933 geschreven, evenmin aan deze analyse ontsnapt zou zijn.

Naast deze controverse tussen theorie en praktijk is de toestand in Nederland ook onbevredigend omdat, voorzover van een algemeen aanvaard standpunt kan worden gesproken, dit standpunt ver verwijderd is van de wijze waarop het accountantsberoep in de rest van de wereld, en ik denk hierbij met name aan de Angelsaksische gebieden, wordt uitgeoefend. Het komt mij, gezien de voortschrijding van de internationale economische integratie en het daarmede samenhangende veelvuldiger contact met buitenlandse accountants, noodzakelijk voor dat gepoogd wordt de afstand die er op dit punt bestaat, te overbruggen of althans te verkleinen.

Ik meen dat de onbevredigende toestand mede te wijten is aan het ontbreken van een steekproefmethode die het „Kleerekoperprobleem” oploste op zodanige wijze, dat een eenvoudige methodiek ook inderdaad leidde tot aanzienlijke besparingen in de praktijk. De principieel juiste benadering van het probleem door De Wolff gaf in dat opzicht resultaten, die voor praktische toepassing nog niet aanlokkelijk genoeg waren.

In dit artikel zal een nieuwe steekproefmethode worden geïntroduceerd, waarvan ik hoop dat deze tot een doorbreking van deze impasse zal kunnen bijdragen. Voorts zal een poging gedaan worden de omvang van steekproeven meer objectief te bepalen op grond van het economisch motief terwijl daarbij tevens getracht zal worden aan te tonen (eveneens op grond van het economisch motief), dat de steekproefomvang een vermindering dient te ondergaan, naarmate de interne organisatie en controle sterker zijn.

\section{Bestaande literatuur}

Afgezien van de artikelenreeks die bekend staat als de strijd tussen de „modernen” 
en de „klassieken”, in welke artikelen de steekproef weliswaar een rol speelde, doch waarin een principiële analyse van het steekproefprobleem achterwege bleef, zijn in Nederland na de oorlog slechts enkele pogingen gedaan de steekproef als middel van accountantscontrole stelselmatig te onderzoeken.

In de eerste plaats is door De Wolff in een voordracht voor de Statistische Dag 1956 een steekproefmethode ontwikkeld, die specifiek op de behoefte van accountants was ingesteld, welke methode in de kring der accountants kritisch is besproken door Cohen 3). In de tweede plaats is door Louwers 4) na een zeer uitgebreide literatuurstudie tot de roelaatbaarheid (onder bepaalde voorwaarden) van de steekproef geconcludeerd. Goudeket 5) sluit zich vrijwel bij het door Louwers opgestelde betoog aan. Tenslotte heeft Drs. H. Meij 6) het gebruik van steekproeven verdedigd. Voor de volledige voordracht van De Wolff zij verwezen naar de publikatie daarvan 2), terwijl voorts in de beschouwing van Cohen eveneens een vrij volledige weergave is opgenomen. Te dezer plaatse zou ik slechts willen weergeven de uitspraak die op grond van een volgens deze methode uitgevoerde steekproef kan worden gedaan:

Indien bij de steekproef geen fout wordt aangetroffen, overschrijdt, behoudens een berekenbare kans op het tegendeel, een eventuele fout waardoor het totaalbedrag wordt verhoogd een bepaald bedrag niet.

Door Cohen 3 ) is deze methode gematigd afwijzend behandeld. Deze ziet de bezwaren voornamelijk in het risico-element, waarmede hij een ten tonele gevoerde opdrachtgever vergeefs laat worstelen, alsmede in het feit dat de steekproefcontrole slechts in één richting effectief is. Ik zou hier slechts willen vragen: Waarom is de schade van een verkeerde beslissing onberekenbaar zoals Cohen stelt, nu de uitspraak uitdrukkelijk de eventuele fout aan een maximum bindt? En waarom is van de voorwaarden voor een rationeel aanvaarden van een risico dat een verkeerde beslissing wordt genomen er geen op ons geval van toepassing? Indien wij de redenering van Cohen zouden aanvaarden, zou de inschakeling van een accountant voor een opdrachtgever bij voorbaat irrationeel zijn. Hij heeft immers ook een (zij het wellicht zeer kleine) kans dat de accountant zijn arbeid niet deugdelijk verricht, om nog maar te zwijgen van die mogelijkheden, waar het axiomatisch voorbehoud op van toepassing is.

Het is te betreuren dat de wijze waarop De Wolff het steekproevenprobleem heeft benaderd niet diepergaand is onderzocht. Hierbij heeft vermoedelijk een rol gespeeld de streng mathematische wijze waarop hij zijn bijdrage heeft gebracht, terwijl een voor accountants praktisch hanteerbaar voorschrift achterwege bleef.

Het is jammer dat Louwers, die toch zo'n uitgebreide literatuurstudie heeft verricht, deze principieel belangrijke voordracht met één zin afdoet, waar hij zegt: „De uitspraak van Cohen, dat genoemde publikatie van De Wolff baanbrekend is op het gebied van het Kleerekoperprobleem .... zal De Wolff zeker niet voor zijn rekening willen nemen."

De verklaring kan naar mijn mening slechts liggen in het feit dat Louwers van een ander uitgangspunt uitgaat. $\mathrm{Na}$ de Amerikaanse literatuur op vele punten met kennelijke instemming te hebben geciteerd, stelt hij ,,dat de accountant in het raam van de volkomen controle het overblijvende deel zodanig moet onderzoeken als nodig is om de stellige overtuiging te verwerven dat de interne controle in de te onderzoeken periode dusdanig is geweest, dat de juistheid van de niet specifiek onderzochte posten waarschijnlijk is." In dezelfde richting wijst zijn betoog dat 
de grotere diepgang van de controle, de uitvoering door hoger gekwalificeerde krachten, alsmede de voorbereiding van de steekproef waarbij de organisatie diepgaand wordt onderzocht, evenzovele voordelen zijn die het verlaten van de volledige waarneming wellicht kunnen compenseren. Zolang niet is aangetoond, dat de steekproefsgewijze controle uit eigen waarneming moet leiden tot ontdekking van fouten zodra de totale omvang daarvan een bepaalde, ten opzichte van het totaalbedrag der onderzochte cijferreeks toelaatbare tolerantie overschrijdt, kan deze redenering niet anders inhouden dan dat Louwers wil steunen op de interne controle, nadat hij de goede werking daarvan diepgaand heeft onderzocht. Hij blijft echter aarzelen de stap ook principieel te doen en noemt het een „open vraag" of de qualitatieve verbetering van de steekproefsgewijze controle niet ruimschoots opweegt tegen de grotere zekerheid van volledige waarneming. Slechts terloops zij daarbij opgemerkt dat hij de betekenis van de eigen actie wel wat al te gemakkelijk afdoet door het voor te stellen alsof de meerdere zekerheid van de volledige waarneming slechts gegrond zou zijn op de gedachte: „meer werk dus meer zekerheid".

Ook de eindconclusie dat de steekproef als middel van accountantscontrole toelaatbaar zou zijn wordt met de nodige voorbehouden omkleed:

„(dat) de steekproef onder daarvoor geschikte omstandigheden en in organische verbondenheid met alle andere controlemiddelen een plaats kan innemen in een volkomen controle."

Ik meen echter dat een volkomen controle reeds inhoudt dat het geheel van controlemiddelen een organische verbondenheid vormt. Dat hierdoor de steekproef met extra waarborgen zou worden omringd is slechts schijn.

Meij stelt zich principieel op het standpunt „dat bij een goed systeem van interne controle de detailcontrole als primaire controlemaatregel nergens anders op gericht behoeft te zijn dan op het constateren of de interne controle inderdaad ook goed gewerkt heeft" en komt dan tot de conclusie dat deze constatering door middel van steekproeven mag geschieden. Het is nuttig op deze gedachtengang wat dieper in te gaan. Het gebruik van steekproeven kan slechts in aanmerking komen ten aanzien van die gebieden waar sprake is van (massale) detailcontrole. Goede werking van de interne controle houdt niet alleen in dat de voorgeschreven formele handelingen worden verricht, doch ook, dat eventuele bij de originele handelingen gemaakte fouten in (vrijwel) alle gevallen worden geconstateerd en hersteld. Nemen wij nu eens aan dat bij de originele handeling in 3 van de 100 gevallen een fout wordt gemaakt. Nemen wij verder aan dat aan de interne controle als eis gesteld mag worden, dat zij van de gemaakte fouten er niet meer dan 3 van de 100 over het hoofd ziet. Nu leert een van de aanvang af goede post niets omtrent de goede werking van de interne controle. Slechts een aanvankelijk foute post die door de oplettendheid van de interne controle is geredresseerd geeft in dit opzicht een aanwijzing. Wil men met enige behoorlijke zekerheid (b.v. $95 \%$ constateren dat de tolerantie ten aanzien van de werking der interne controle niet wordt overschreden, dan zal men ten aanzien van tenminste 100 gevallen, waarin in eerste instantie fouten zijn gemaakt, moeten constateren dat zij alle door de interne controle zijn opgespoord en hersteld. Een eenvoudige berekening leert, dat men dit aantal gemiddeld eerst zal bereiken na onderzoek van ca. 3.300 posten. In het bovenstaande zijn nog vrij ruime percentages gekozen. Zou men in het „ongelukkige" geval komen te verkeren dat de functionaris die de originele handeling 
verricht een zeer accuraat werker is, dan zou de steekproef wel eens tot astronomische getallen kunnen oplopen alvorens men het benodigde aantal fouten in zijn werk bijeen heeft om de ,goede werking" van de interne controle daarop te kunnen constateren. En na al deze moeite blijft dan nog het „Kleerekoperprobleem" dat de enkele foute post die het systeem passeert in geval van fraude of doorbreking van bovenaf wel eens een relatief grote zou kunnen zijn. De mededeling van Meij dat de dekking daartegen veel goedkoper door de fraudeverzekering kan worden verkregen is niet steekhoudend. De fraude zal immers geconstateerd moeten worden om de schadeloosstelling te kunnen incasseren en dat zal in geval van doorbreking van de interne controle slechts door de accountant kunnen geschieden. Bovendien is het begrip fraude hierbij te eng gezien. Fraude kan namelijk ook bestaan in het doelbewust geven van een verkeerd beeld in de verantwoording en het daardoor benadelen van belanghebbenden. Het voorkomen daarvan is toch wel specifiek het terrein des accountants.

Ik meen daarom dat het nagaan van de goede werking van de interne controle nimmer een goede basis kan vormen voor de verdediging van het gebruik van steekproeven.

Merkwaardig in het artikel van Meij is tenslotte dat deze schrijver, die principieel de werking der interne controle tot object van onderzoek verklaart, vrij uitvoerig en met instemming ingaat op het werk van De Wolff, dat toch juist is afgestemd op de rechtstreekse eigen actie ten aanzien van de te controleren totalen.

Een ware lawine van literatuur op het gebied van de steekproef is voornamelijk na de oorlog in de Verenigde Staten losgekomen. Dat hierbij kwantiteit niet altijd ten goede komt aan de kwaliteit zal de aandachtige lezer van deze publicaties niet zijn ontgaan. Het is niet mijn bedoeling de Amerikaanse literatuur opnieuw aan een onderzoek te onderwerpen. Louwers heef $t$ dit, voor wat betreft de serieuze auteurs, reeds op voortreffelijke wijze vóór mij gedaan. Wel zou ik als algemene conclusie willen stellen dat men in de Verenigde Staten in principe steeds werkt met aantallen posten. Weliswaar vermeldt Louwers terecht, dat aan de aard van de mogelijke fouten veel aandacht wordt besteed, waarbij als één der criteria dan de grootte van het bedrag wordt vermeld, doch van een systematische uitwerking in dien zin dat de tolerantie wordt uitgedrukt in een percentage van het totaalbedrag der te onderzoeken postenreeks is geen sprake.

Toen de tekst voor deze publicatie reeds geheel gereed was verscheen het septembernummer van dit maandblad, waarin een kritische beschouwing betreffende de door De Wolff geïntroduceerde steekproefmethode voor accountants van de hand van Prof. A. Meij is opgenomen.

Deze beschouwing voert ten onrechte de verbandcontrole ten tonele als tegenhanger van steekproeven en overschat daarmede aanzienlijk de rol die steekproeven zichzelf in de controleleer willen toebedelen. Steekproeven zoals door De Wolff behandeld, willen slechts een beperking opleveren in die gevallen waarin de controleleer tot een (massale) detailcontrole besluit. Het karakter van de gelaagde steekproefmethode wordt voorts miskend, wanneer we zien dat Prof. Meij deze methode als analoog beschouwt aan hetgeen hijzelf als afromen betitelt. Bij dit laatste wordt getracht door belangrijke delen te controleren een zeer groot percentage van de totaal in het geding zijnde bedragen te omvatten. Dit heeft echter slechts de uiterlijke verschijningsvorm met de methode De Wolff gemeen. Hierin is het grensbedrag waarboven men alles controleert slechts het middel tot het doel.

$\mathrm{m} \mathrm{a} \mathrm{b}$ blz. 456 
Of de op deze wijze gecontroleerde posten tezamen een belangrijk deel van het te controleren totaalbedrag uitmaken is daarbij irrelevant en dit deel kan onder bepaalde verhoudingen zelfs zeer gering zijn.

In deze miskenning ligt vermoedelijk ook de grond voor de eindconclusie, die de methode De Wolff terugwijst tot een heldere formulering van iets wat wij al lang wisten.

\section{Stratificatie-methode}

De eerste, die bij de probleemstelling uitgaat van een tolerantie uitgedrukt als percentage van het totaalbedrag, is De Wolff in zijn eerder genoemde voordracht. Diens uitwerking mag ik na de kritische bespreking van Cohen 3) als bekend veronderstellen. Tegen de wijze waarop De Wolff zijn methode in eerste instantie heeft gebracht bestonden verschillende bezwaren uit zuiver technisch oogpunt. Doordat De Wolff als rechtgeaard statisticus onmiddellijk zocht naar het optimale punt $\mathrm{x}_{0}$ waarbij, gegeven een bepaald voorschrift, de omvang van de steekproef minimaal werd, ontstond een wiskundige problematiek die de methode voor directe toepassing door accountants ontoegankelijk maakte. Daarnaast veroorzaakte de stratificatie in slechts 2 lagen een steekproefomvang, die nog weinig bemoedigend was voor accountants. In een latere publicatie 7) heeft dezelfde auteur de methode, analoog aan een door mij ontwikkelde stratificatie-methode (niet gepubliceerd), verder uitgebouwd. Hierbij kan de massa in willekeurige grootte-klassen worden ingedeeld, waarbij in iedere grootte-klasse een gedeelte van de daarin vallende posten wordt gecontroleerd. De te controleren fractie wordt bepaald door de volgende formule:

$$
1-\left(1-\frac{P}{T}\right) \frac{\ln \varepsilon}{\ln (1-\varphi)}
$$

waarin: $\mathrm{P}=$ bovengrens van de grootte-klasse

$\mathrm{T}$ - totaalbedrag van de gehele te controleren postenreeks

$\varepsilon=$ de kans op een onjuiste uitsprak

$\varphi=$ de fractie van het totaalbedrag der te controleren massa, die als toelaatbare grens wordt gekozen (fout-tolerantie)

Ik merk hierbij op dat dezc formule de door mij ontwikkelde weergeeft, de annotatie van De Wolff wijkt daar iets van af, doch in wezen zijn de 2 formules uiteraard identiek. Voor de bewijsvoering dat het gestelde doel t.a.v. foutentolerantie en waarschijnlijkheid bereikt wordt zij verwezen naar de aan het eind van dit artikel opgenomen appendix.

De gegeven formule, die op het eerste gezicht nog enigszins ingewikkeld aandoet, blijkt bij nadere beschouwing in feite van een verrassende eenvoud. Bezien wij daartoe eerst de exponent

$$
\frac{\ln \varepsilon}{\ln (1-\varphi)}
$$

$\varepsilon$ en $\varphi$ stellen tezamen de betrouwbaarheid van de steekproef voor. In tabel I zijn de uitkomsten van deze exponent voor enkele combinaties van $\varepsilon$ en $\varphi$ weergegeven: 


\begin{tabular}{l|rrrr} 
Tabel I & & Waarden van & $\frac{\ln x}{\ln (1-\varphi)}$ \\
\hline 0,001 & 6910 & 4600 & 3910 & 3000 \\
\hline 0,01 & 690 & 459 & 390 & 300 \\
\hline 0,02 & 342 & 230 & 195 & 150 \\
\hline 0,05 & 134 & 90 & 76 & 58 \\
\hline
\end{tabular}

Afgezien van het feit dat aan de hand van deze waarden de steekproeffracties per grootte-klasse berekend kunnen worden, geven zij tevens bij benadering het aantal posten, dat in de totale steekproef over alle grootte-klassen tezamen zal worden betrokken, mits het aantal grootte-klassen voldoende groot genomen is en de grenzen goed zijn gekozen.

Keren wij thans terug tot de formule voor de in elke grootte-klasse te controleren fractie, in welke formule wij de exponent vervangen door $n$, zijnde de benaderde steekproefomvang voor de gehele massa. Aangezien $\frac{P}{T}$ practisch steeds een zeer kleine waarde zal hebben, kan de formule zonder groot bezwaar als volgt worden geschreven:

$$
1-\left(1-\mathrm{n} \frac{\mathrm{P}}{\mathrm{T}}\right)=\frac{\mathrm{P}}{\mathrm{T} / \mathrm{n}}
$$

en het voorschrift is dan al zeer eenvoudig geworden.

Het volgende cijfervoorbeeld is wellicht nuttig als illustratie.

Stel dat wij een postenreeks willen controleren, die een totaaltelling aanwijst van $f 100.000$,- . Stel verder dat wij als foutengrens willen aanvaarden $5 \%$ van dit totaalbedrag zijnde $f 5.000$,- en dat wij een waarschijnlijkheid eisen van $99 \%$ dat, indien zich een fout van $f 5.000$, - zou voordoen, wij dit zullen merken; of anders gezegd dat wij bereid zijn een risico van $1 \%$ te lopen dat een fout groot $\int 5.000$,- niet door ons zal worden bemerkt. In de tabel kunnen wij aflezen, dat de totale (benaderde) steekproefomvang 90 dient te zijn:

$\frac{\mathrm{T}}{\mathrm{n}}$ wordt dan $\frac{f 100.000,-}{90}=f 1.111$,

Voor een aantal grootte-klassen krijgen wij dan de volgende steekproef-fracties: 


\begin{tabular}{|c|c|c|}
\hline Grootte-klasse & e & ekproeffr. \\
\hline \multirow{2}{*}{ f $100,--f 200$} & 200 & \multirow{2}{*}{$=0,18$} \\
\hline & 1111 & \\
\hline \multirow{2}{*}{$f 200,--f 300,-$} & 300 & \multirow{2}{*}{$=0,27$} \\
\hline & 1111 & \\
\hline \multirow{2}{*}{$f 300,--f 400,-$} & 400 & \multirow[t]{2}{*}{$=0,36$} \\
\hline & 1111 & \\
\hline \multirow{2}{*}{$f 400,--f 500,-$} & 500 & \multirow{2}{*}{$=0,45$} \\
\hline & 1111 & \\
\hline
\end{tabular}

Opgemerkt zij dat bij posten boven $f 500,-$ de eerdergenoemde vereenvoudiging in de formule (B) de steekproeffractie geleidelijk meer naar boven doet afwijken van de exact benodigde volgens formule (A). Gemakkelijk valt in te zien, dat het aantal posten boven $f 500$, - in een totaalbedrag van $f 100.000$, - niet zeer groot kan zijn, zodat ook het bezwaar van de vereenvoudigde formule niet groot is. In ieder geval doet men meer dan vereist is en wordt dus de geëiste betrouwbaarheid niet aangetast.

Naast de betrekkelijke eenvoud van het voorschrift, levert deze stratificatiemethode ten opzichte van de door De Wolff in zijn eerste voordracht gegeven methode een aanzienlijk grotere besparing op. Berekende deze voor $\varphi=0,01$ en $\varepsilon=0,01$ een benodigd steekproefaantal van ca. 1500 , dit aantal tendeert bij de stratificatiemethode (nogmaals: mits een voldoend aantal grootte-klassen of strata wordt genomen) naar 459.

Toch levert de stratificatie-techniek bij strikte toepassing zekere bezwaren op. De voorbereiding eist namelijk dat voor elke grootte-klasse afzonderlijk de steekproeffractie wordt bepaald en het voorgeschreven aantal ,at random" wordt geselecteerd. Weliswaar heeft collega Rietveld voor deze selectie een verkorte methode ontworpen (niet gepubliceerd) doch ook hierbij moet de gehele massa één keer worden doorgelopen, terwijl bovendien de tellingen geheel moeten worden gecontroleerd.

\section{Guldenrangnummermethode}

Mede met het oog op de bezwaren tegen de stratificatiemethode, doch ook omdat uit anderen hoofde m.i. belangrijke voordelen konden worden bereikt, ben ik gekomen tot een steekproefmethode, die ik voorshands de ,guldenrangnummermethode" heb gedoopt. Hierbij wordt de wijze waarop een te controleren postenreeks zich in feite manifesteert, geheel losgelaten en (in gedachten) getransformeerd in een reeks guldens, die (slechts toevallig) in posten van verschillende grootte zijn samengebracht. Aan elke gulden in deze reeks wordt nu een eigen rangnummer gegeven. E.e.a. kan worden gedemonstreerd aan de hand van de volgende eenvoudige postenreeks: 


\begin{tabular}{|c|c|c|c|}
\hline Post nr. & Bedrag & $\begin{array}{c}\text { Cumulatief } \\
\text { totaal }\end{array}$ & $\begin{array}{c}\text { Guldenrang- } \\
\text { nummers }\end{array}$ \\
\hline 1 & f $10,-$ & $f \quad 10,-$ & $1 \mathrm{t} / \mathrm{m} \quad 10$ \\
\hline 2 & $, \quad 25,-$ & $\Rightarrow \quad 35,-$ & $11 \mathrm{t} / \mathrm{m} 35$ \\
\hline 3 & $" 100,-$ & , $135,-$ & $26 \mathrm{t} / \mathrm{m} 135$ \\
\hline 4 & $" 50,-$ & $, 185,-$ & $136 \mathrm{t} / \mathrm{m} 185$ \\
\hline \multirow[t]{2}{*}{5} & $\Rightarrow \quad 75,-$ & ", 260,- & $186 \mathrm{t} / \mathrm{m} 260$ \\
\hline & $f 260,-$ & & \\
\hline
\end{tabular}

Aan de hand van dit voorbeeld zal het duidelijk zijn dat ieder guldenrangnummer niets anders is dan het cumulatieve totaal tot en met de daardoor aangeduide gulden en het hoogste guldenrangnummer wordt gevormd door het eindtotaal van de gehele postenreeks. Het is voorts gemakkelijk in te zien dat iedere post in de totale nummerserie voorkomt met een aantal guldenrangnummers dat gelijk is aan het bedrag van die post in guldens. Statistisch is het probleem nu eenvoudig en teruggebracht tot de bekende vaas met witte en rode ballen.

Laten wij aannemen dat in een postenreeks foute posten voorkomen waarvan het gezamenlijk bedrag een fractie $\varphi$ van het totaalbedrag uitmaakt. Per definitie zullen de foute posten gezamenlijk vertegenwoordigd worden door een aantal guldenrangnummers dat eveneens een fractie $\varphi$ van de gehele rangnummerserie uitmakkt. Wordt nu een willekeurig rangnummer uit de serie getrokken dan is de kans:

een foute post te treffen: $\varphi$

een goede post te treffen: $(1-\varphi)$

De kans in een serie van $n$ trekkingen uitsluitend goede posten aan te treffen (m.a.w. van het verschijnsel ,fout" niets te merken) is:

$$
(1-\varphi)^{\mathrm{n}}
$$

Wil men bij een fout-fractie $\varphi$ dus slechts een kans $\varepsilon$ lopen geen fout te vinden, of wat hetzelfde is slechts een kans $\varepsilon$ te lopen de verkeerde beslissing te nemen dat de postenserie goed is, dan zullen wij n zo moeten kiezen dat

$$
(1-q)=\varepsilon
$$

of:

$$
\mathrm{n}=\frac{\ln \varepsilon}{\ln (1-\varphi)}
$$

uit welke vorm men de exponent van formule (A) herkent.

Voor de uitkomst van deze vorm voor enkele combinaties van $\varphi$ en $\varepsilon$ zij wederom verwezen naar tabel 1 . Met behulp van de wiskundige kennis die iedere accountant uit hoofde van zijn opleiding bezit, is de uitkomst voor iedere andere combinatie van $\varphi$ en $\varepsilon$ gemakkelijk te berekenen. De toepassing is nu zeer eenvoudig en het is wellicht nuttig het proces aan de hand van een cijfervoorbeeld te beschrijven.

Stel men heeft een postenreeks met een totaalbedrag van $f 100.000$, - te controleren. Men is tot de conclusie gekomen dat men bereid is een risico van $1 \%$ $(0,01)$ te lopen niets te vinden, indien van het totaalbedrag een fractie van $5 \%$ $(0,05)$ of $f 5.000$, - niet gedekt zou zijn. Uit de formule (C) berekent men dat het daarvoor benodigde aantal in de steekproef 90 moet zijn. Men doet 100.000 loterij-briefjes genummerd $1 \mathrm{t} / \mathrm{m} 100.000$ in een hoed en trekt daaruit 90 wille-

m a b blz. 460 
keurige briefjes. (In de praktijk zal men op minder omslachtige wijze ",random” of a-selecte nummers bepalen door voor verschillende gevallen tevoren lijsten op te stellen). In welke post de guldens zich bevinden die door trekking zijn aangewezen wordt door cumulatief tellen bepaald. Vindt men bij controle van de aldus aangewezen posten geen fouten, dan staat dus (behoudens een kans op het tegendeel van $1 \%$ ) vast dat van dat totaalbedrag minder dan $f 5.000$, - ongedekt is.

De methode heeft nog een tweetal aantrekkelijke eigenschappen, die op het eerste gezicht wat ongeloof waardig aandoen. Ik zou willen beginnen deze eigenschappen te geven:

(a) de methode wijst als object van controle aan niet een post doch een bepaalde gulden van die post. Dat wil zeggen: indien het nummer de 50ste gulden treft van een post groot $f 100$,- en het stuk dat deze post moet dekken geeft slechts $f 80$,- aan, dan is de aangewezen gulden gedekt en de uitspraak omtrent het totaalbedrag wordt niet aangetast.

(b) bij de aanwijzing van de te controleren post op grond van een bepaald rangnummer kan direct van het hoogste daaraan voorafgaande subtotaal worden uitgegaan met cumulatief tellen. Op grond van het tellen, verricht ter selectie van de posten heeft men, zonder enig verder telwerk, de totaaltelling gecontroleerd met dezelfde betrouwbaarheid als voor het constateren van fouten tot uitgangspunt is gekozen.

Het best is e.e.a. te demonstreren aan de hand van een eenvoudig cijfervoorbeeld.

\begin{tabular}{|c|c|c|c|c|}
\hline \multirow{2}{*}{$\begin{array}{c}\text { Bedrag v/h } \\
\text { stuk }\end{array}$} & \multicolumn{2}{|c|}{ Boekingen } & \multirow[b]{2}{*}{ Rangnummers } & \multirow{2}{*}{$\begin{array}{l}\text { „Foute" } \\
\text { rangnummers }\end{array}$} \\
\hline & Post nr. & Bedrag & & \\
\hline$f \quad 25,-$ & 1 & f $25,-$ & $1 \mathrm{t} / \mathrm{m} \quad 25$ & - \\
\hline$" 30,-$ & 2 & $, \quad 30,-$ & $26 \mathrm{t} / \mathrm{m} \quad 55$ & - \\
\hline$\Rightarrow \quad 50,-$ & 3 & $, \quad 50,-$ & $56 \mathrm{t} / \mathrm{m} 105$ & - \\
\hline$" \quad 5,-$ & 4 & $" \quad 5,-$ & $106 \mathrm{t} / \mathrm{m} 110$ & - \\
\hline & subtotaal & $f 120,-$ & & $111 \mathrm{t} / \mathrm{m} 120$ \\
\hline$\leadsto 75,-$ & 5 & $, 75,-$ & $121 \mathrm{t} / \mathrm{m} 195$ & - \\
\hline $10,-$ & 6 & $" 10,-$ & $196 \mathrm{t} / \mathrm{m} 205$ & - \\
\hline$, 100,-$ & 7 & $, 100,-$ & $206 \mathrm{t} / \mathrm{m} 305$ & 一 \\
\hline & subtotaal & $f 325,-$ & & $306 \mathrm{t} / \mathrm{m} 325$ \\
\hline $5,-$ & 8 & $, \quad 5,-$ & $326 \mathrm{t} / \mathrm{m} 330$ & - \\
\hline$\Rightarrow \quad 22,-$ & 9 & $, 40,-$ & $331 \mathrm{t} / \mathrm{m} 370$ & $353 \mathrm{t} / \mathrm{m} 370$ \\
\hline$\Rightarrow 90,-$ & 10 & $\Rightarrow 90,-$ & $371 \mathrm{t} / \mathrm{m} 460$ & - \\
\hline$, \quad 20,-$ & 11 & $\Rightarrow 20,-$ & $461 \mathrm{t} / \mathrm{m} 480$ & - \\
\hline$f 432,-$ & Eindtotaal & $f 480,-$ & & $\begin{array}{c}48 \\
\text { rangnummers }\end{array}$ \\
\hline
\end{tabular}


Allereerst wordt er bij dit voorbeeld op gewezen, dat de steekproefmethode slechts leidt tot een gekwantificeerde uitspraak omtrent het eventueel aanwezig zijn van fouten die het totaalbedrag verhogen (positieve controle). Omtrent de volledigheid van het totaalbedrag laat de methode geen oordeel toe. Hier wordt nog nader op terug gekomen. Om deze reden zijn slechts „positieve” (de telling verhogende) fouten verwerkt. Zouden ook negatieve fouten voorkomen, dan moet uiteraard het gezamenlijk bedrag der positieve fouten dienovereenkomstig hoger zijn om toch tot een bepaalde afwijking naar boven van de eindtelling der postenreeks te geraken. Het behoeft geen betoog, dat de ontdekkingskans van deze positieve fouten dan alleen maar groter wordt.

In dit voorbeeld is een totaalfout van $10 \%$ of $f 48,-$ gemaakt, gedeeltelijk door telfouten $(f 30,-)$ gedeeltelijk door te hoge boeking $(f 18,-)$. Bij bestudering van dit voorbeeld blijkt dat de "fout", of dit nu een te hoge boeking of een telfout is, in de „hoed" vertegenwoordigd moet zijn met een aantal rangnummers, dat gelijk is aan het totaalbedrag van die fout en dus onderworpen aan de eerder gegeven waarschijnlijkheidsberekening. Men lette daarbij op het feit dat als foute rangnummers alleen zijn beschouwd de laatste 18 van post 9 (eigenschap a.) en dat de guldens van de posten na elk subtotaal zijn genummerd van dat subtotaal uitgaand. (eigenschap b.)

Een wat strenger bewijs kan als volgt gegeven worden. De guldenrangnummers van iedere post zijn gedefinieerd als te beginnen na:

(hoogst voorafgaand subtotaal + de posten tussen dat subtotaal en de betreffende post).

Op deze wijze kunnen de guldens in iedere post slechts op één wijze genummerd worden en het aantal nummers in elke post is dus gelijk aan het bedrag daarvan. Door de guldens in iedere post per definitie in volgorde te laten dekken door het corresponderende stuk, staat indirect voor elk stuk bij voorbaat vast welke rangnummers daardoor worden gedekt en wel voor elk stuk een aantal dat gelijk is aan het bedrag van het stuk. Bij voorbaat staat dan vast dat het in de gehele massa voorkomende aantal rangnummers dat bij controle als gedekt wordt beschouwd gelijk is aan het totaalbedrag der stukken. Indien het totaalbedrag van de postenreeks dit totaalbedrag van de stukken (door welke oorzaak dan ook) overschrijdt, zal deze overschrijding in een aan die overschrijding gelijk zijnd aantal ,ongedekte" rangnummers tot uitdrukking moeten komen.

Ook na deze theoretische fundering zal bij de lezer mogelijk nog twijfel rijzen hoe de totaaltelling gecontroleerd kan zijn zonder dat er één bladzijde geheel wordt nageteld. Dit laatste is echter niet geheel juist. Een deel der steekproeven zal namelijk een rangnummer betreffen dat dicht bij de transporttelling naar de volgende bladzijde ligt. Het constateren van een telfout zal zich dan manifesteren doordat men zoekt naar een rangnummer, dat hoger is dan de transporttelling bovenaan de bladzijde plus de op die bladzijde voorkomende posten. In het gegeven voorbeeld zoekt men dan één van de nummers $111 \mathrm{t} / \mathrm{m} 120$ of $306 \mathrm{t} / \mathrm{m} 325$. Men kan dit zelf controleren door zestien willekeurige getallen onder 481 te kiezen. Men neemt hiervoor bijvoorbeeld de laatste drie cijfers van de nummers uit een telefoonboek bij voorkeur uit een plaats met nummers van 5 of 6 cijfers. Vormen de laatste drie cijfers een getal van 481 of hoger dan worden deze overgeslagen.

Voorspeld kan dan worden, dat er $63 \%$ kans bestaat in één der twee telfouten 
te prikken en $82 \%$ kans in één van alle 48 foute rangnummers. Herhaalt men series van 16 steekproeven een aantal malen, dan zal gemiddeld in $2 / 3$ van de gevallen de telfouten geraakt worden. De kans, dat het na 4 of 5 series van 16 stuks nog niet gebeurd zou zijn, is zeer gering $( \pm 1 \%)$.

De voordelen ten aanzien van het telwerk zullen in de praktijk naar zich laat aanzien in het algemeen niet overweldigend zijn. Ruwweg zal men immers voor elke post in de steekproef gemiddeld een halve bladzijde, sheet of dergelijke moeten tellen. Slechts indien het steekproefaantal gelijk is aan of kleiner is dan het aantal pagina's zal van een merkbare besparing sprake zijn. Hier staat echter weer tegenover dat na iedere aangeslagen post de telling moet worden geraadpleegd in verband met de selectie der te controleren posten. Een telmachine van het type comptometer met permanente registratie van het cumulatieve totaal lijkt hier aangewezen.

De aanwijzing van een specifieke gulden als controleobject biedt echter ook in andere opzichten interessante aspecten. Zonder volledig te zijn zou ik hier enkele voorbeelden van willen noemen.

1. Bij de afloopcontrole op een debiteur waarvan het saldo uit meerdere openstaande facturen bestaat, behoeft slechts van de door het rangnummer getroffen factuur de afloop te worden nagegaan.

2. Indien bij inventarisatie bijv. de $5 \mathrm{e}$ eenheid van een partij van 100 stuks wordt getroffen, zal men in één oogopslag kunnen constateren dat de 5e eenheid in ieder geval aanwezig is en exacte telling achterwege kunnen laten. Bij inventarisatie van verpakte goederen zou het de aanwijzing kunnen opleveren welke specifieke eenheid ter controle van de inhoud geopend moet worden, welke baal specifiek moet worden nagewogen etc.

3. Bij de controle op samengestelde loonberekeningen zal tot object van nader onderzoek een bepaald loonbestanddeel van een bepaalde werknemer worden aangewezen.

Daarnaast is echter belangrijk, dat een te hoge boeking geen fout in de zin van de steekproef oplevert indien de aangewezen gulden maar gedekt is. Daardoor wordt vermeden dat een relatief niet belangrijke fout tot aanzienlijke uitbreiding van het onderzoek aanleiding zou moeten geven. Althans ten aanzien van het criterium: ,grootte van de fout" is hierdoor de betekenis van een gevonden fout automatisch bepaald. Contra rationem uitgedrukt: Men loopt minder ,risico” een fout te vinden.

Hier moet een misverstand vermeden worden. Een aldus gevonden fout, hoewel geen fout in de zin van de steekproef, zal uiteraard grondig worden onderzocht teneinde de oorzaak vast te stellen. Hoever de accountant hiermede moet gaan zal zijn vakkennis hem voorschrijven. Echter, de uitspraak die hij zich bij de aanvang van de steekproef als doel had gesteld, blijft onaangetast en er zijn dus geen statistische gronden de omvang van de steekproef uit te breiden.

Ik meen dat de ,guldenrangnummermethode”, zoals hiervoor uiteengezet aanzienlijke voordelen biedt. Voorzover na te gaan is hiermede, afgezien van de bijkomende voordelen, de grens van eenvoud in voorschrift en minimale omvang van de steekproef bereikt. Er moet echter wel op worden gewezen, dat de voor- 
delen uitsluitend liggen in het technisch-statistische vlak. De uitspraak, die op grond van deze methode gedaan kan worden is identiek gebleven aan die, welke door Prof. De Wolff in zijn voordracht voor de Statistische Dag 1956 is geformuleerd nl.:

Indien in de steekproef geen enkele fout wordt aangetroffen, kan behoudens een waarschijnlijkheid $\varepsilon$ worden aangenomen, dat het toelaatbare totaalbedrag niet meer dan een fractie $\varphi$ onder het getoonde totaalbedrag van de onderzochte postenreeks ligt. De waarden voor $\varepsilon$ en $\varphi$ kunnen naar behoefte worden vastgesteld en bepalen de noodzakelijke omvang van de steekproef.

\section{Plaats van de steekproef in de controleleer}

Statistiek is geen controleleer. Het is een hulpwetenschap die ons een bepaalde verkorte waarnemingstechniek voor massale verschijnselen aanbiedt, waarbij in exacte cijfers kan worden aangegeven welke nauwkeurigheid respectievelijk betrouwbaarheid het resultaat van de waarneming heeft. Slechts de controleleer kan bepalen welke gebieden waargenomen moeten worden, op welke wijze de waarneming dient te geschieden en welke eisen aan het resultaat van de waarneming moeten worden gesteld. Zeer terecht heeft ook Louwers dit reeds gesteld.

Wij hebben in het voorgaande geïnventariseerd wat de statistiek aan te bieden heeft, doch zullen thans moeten onderzoeken of de controleleer hier iets mee kan doen. Het onderzoek kan daarbij beperkt worden tot die gebieden, waar de controleleer een detailcontrole voorschrijft. Immers alleen daar is sprake van massale waarneming. Een nadere analyse van wat detailcontrole inhoudt is daartoe noodzakelijk.

\section{Analyse van bet begrip detailcontrole}

Ik meen detailcontrole te mogen omschrijven als het verifï̈ren van een reeks in de administratie voorkomende posten aan de hand van een corresponderende reeks andere gegevens, welke laatste gegevens de rechtvaardiging van de postenreeks moeten opleveren. Meer populair gezegd: de te controleren postenreeks wordt dichtgehaakt. Ten aanzien van de volledigheid van de postenreeks geeft de detailcontrole ons in principe geen zekerheid, tenzij de volledigheid van de gegevens waarmede gecontroleerd wordt bij voorbaat vaststaat. En deze laatste zekerheid zal als regel slechts door interne controlemaatregelen kunnen worden verkregen (aansluitende nummerseries, controle of voor alle goederenontvangsten facturen zijn ontvangen etc.). Door eigen actie zal de accountant in het algemeen slechts de relatieve volledigheid t.o.v. andere postenreeksen kunnen constateren, doch dit geschiedt niet middels detailcontrole. Slechts als voorbeeld zou ik willen noemen:

a. De relatieve volledigheid van geboekte facturen volgt uit het verband met het betalingsverkeer en de van dat verkeer uit verrichte controle op de volledigheid der crediteuren.

b. De relatieve volledigheid der debiteuren volgt uit het verband met de verkopen enerzijds en het betalingsverkeer anderzijds. 
Ik meen te mogen stellen dat detailcontrole vrijwel steeds is een positieve controle, m.a.w. een controle slechts gericht op de toelaatbaarheid. Men begrijpe mij goed. Ik ontken niet dat bij detailcontrole sommige fouten, die de volledigheid aantasten, kunnen worden ontdekt, zoals bijv. een te lage boeking. Het betreft echter slechts een „kunnen ontdekken”, niet een alle fouten-mogelijkheden uitsluitende controle zoals deze in het kader van een volkomen controle wordt nagestreefd. Indien men op grond van dit ,kunnen ontdekken” de volledigheid van de detailcontrole zou willen verdedigen, dan zou met evenveel recht geëist kunnen worden dat de volledige ingangszijde van de voorraadadministratie naar geboekte inkoopfacturen wordt doorgecheckt of alle copie-verkoopfacturen naar de debiteuren-administratie. En zover zal wel niemand willen gaan.

\section{Doel van de controle}

Alvorens verder te gaan zou ik, teneinde het betoog zo eenvoudig mogelijk te houden, als uitgangspunt willen stellen dat wij spreken over de meest algemene vorm van accountantscontrole nl. die gericht op de normale controle van de jaarrekening. Niet omdat ik meen dat bij andere controledoeleinden voor de steekproef geen plaats zou zijn, doch slechts om te vermijden dat door het stellen van allerlei casus-posities de discussie nodeloos zou kunnen worden vertroebeld. Indien de steekproef als middel van accountantscontrole algemeen zou worden aanvaard, kan het naar mijn mening aan de individuele accountant worden overgelaten om in elk specifiek geval van zijn kennis van de controleleer uit te bepalen in hoeverre hij bij een onderzoeking met een bijzonder doel de steekproef kan toepassen.

\section{Nadere analyse van de betrouwbaarheid van het steekproefresultaat}

De betrouwbaarheid van het resultaat van de steekproef bevat drie elementen, namelijk:

1. Alleen een overschrijding van het toelaatbare wordt ontdekt.

2. Slechts een fout van bepaalde grootte $(\varphi)$ zal worden ontdekt.

3. Men heeft geen absolute zekerheid dat een fout groot $\varphi$ zal worden ontdekt, doch loopt een risico $(\varepsilon)$ niets te merken.

Ik hoop bij de nadere analyse van de detailcontrole angetoond te hebben, dat de detailcontrole vrijwel steeds is een positieve controle. Indien dit zo is staat reeds dadelijk vast dat het eerste element de toepassing van steekproeven niet in de weg staat.

Het tweede element is het tolerantie-element. Hier kunnen wij geloof ik, kort zijn. Een goedkeurende verklaring bij een jaarrekening houdt geen ander oordeel in dan dat het door de jaarrekening gegeven beeld een getrouwe weergave is van de financiële positie en de behaalde resultaten. Dat beeld kan reeds daarom niet exact zijn, omdat in veel posten van de jaarrekening een element van schatting onvermijdelijk is. Daarenboven is het beeld mede afhankelijk van de grondslagen die bij de opstelling van de jaarrekening zijn gevolgd. Het moet economisch niet rationeel geacht worden ten aanzien van die elementen, die wellicht in principe een grotere nauwkeurigheid toelaten, extra kosten te maken om deze grotere nauwkeurigheid te bereiken indien daardoor het beeld van de jaarrekening als geheel niet wordt verbeterd. Er wordt dan immers aan de waarde van de jaar- 
rekening als informatie-bron en derhalve ook aan de waarde van de accountantsverklaring bij die jaarrekening niets toegevoegd. Ook Louwers komt tot deze conclusie.

Het tolerantie-element als zodanig zal dan ook geen argument tegen het gebruik van de steekproef kunnen vormen.

Het voornaamste probleem zie ik in het risico-element. Zelfs Cohen 3), die toch als statisticus met het risico-element, dat aan steekproeven inhaerent is, vertrouwd moet zijn ziet hierin een onoverkomelijke moeilijkheid. Deze moeilijkheid ligt, meen ik, bij het volgende. De accountant zal indien hij een zekere tolerantie $(\varphi)$ bepaald heeft ook wel een bepaald risico willen lopen dat een fout van die omvang niet ontdekt wordt. Immers het begrip tolerantie houdt per definitie in, dat de daardoor aangegeven afwijking getolereerd kan worden. Echter er bestaat ook een kans dat een fout die de tolerantie overschrijdt niet ontdekt zal worden en het is hier dat het onbehagen begint. Een nader onderzoek van dit risicoelement is daarom gewenst. Bezien wij daartoe de formule $\varepsilon=(1-\varphi)^{\mathrm{a}}$ welke voor praktische gevallen waarin $\varphi$ steeds een zeer klein getal zal zijn, bij benadering ook geschreven kan worden als $\varepsilon=\frac{1}{\mathrm{e}^{\mathrm{n} \varphi}}$

Berekenen wij voor een bepaalde vaste steekproefomvang (n) van bijv. 230 de bij elkaar behorende waarden van $\varepsilon$ en $\varphi$ dan krijgen wij het volgende beeld:

\begin{tabular}{l}
$\varphi($ fout $)$ \\
\hline $1 \%$ \\
$2 \%$ \\
$4 \%$ \\
$6 \%$ \\
$8 \%$
\end{tabular}
$\varepsilon$ (risico van niet ontdekking)

0,1
0,01
0,0001
0,000001
0,00000001

We zien hieruit, dat naarmate de eventuele totaalfout in de massa groter is, het risico, dat de fout niet gemerkt zou worden zeer sterk afneemt en al spoedig waarden aanneemt die met 0 gelijk gesteld mogen worden. Op welk punt men deze gelijkstelling wil leggen, is een kwestie van smaak.

Het is deze eigenschap, die een mogelijk aanwezige onontdekte fout praktisch aan een absoluut maximum bindt, die mij de overtuiging geeft, dat ook het risicoelement voor de accountant principieel aanvaardbaar moet zijn. Zou men in bovenstaand voorbeeld het risico dat bijv. bij $4 \%$ fout wordt bereikt niet willen aanvaarden, dan vraag $\mathrm{ik} \mathrm{mij} \mathrm{in} \mathrm{gemoede} \mathrm{af} \mathrm{hoe} \mathrm{bijv.} \mathrm{het} \mathrm{gebruik} \mathrm{maken} \mathrm{van}$ assistenten kan worden verdedigd. Zou men daarbij niet een kans van 1 op 10.000 lopen dat een wat minder goede assistent bij het volledig afhaken van duizenden facturen op een gegeven moment in slaap valt en over fouten heenkijkt?

\section{Toetsing aan de leer van bet gewekte vertrouwen}

Eerder is reeds gesteld dat er in dit betoog wordt uitgegaan van de accountantscontrole, gericht op de verklaring bij de jaarrekening. Deze verklaringen houden niet meer in dan dat de jaarrekening een getrouw beeld geeft van de financiële positie en resultaten. Dit beeld behoeft niet absoluut exact te zijn en kan dit zelfs niet 
zijn. Meerdere schrijvers hebben hier reeds op gewezen. Sommige in Nederland gebruikte formuleringen zouden weliswaar de indruk kunnen wekken verder te willen gaan. Ik meen echter dat ook deze verklaringen niet meer bedoelen dan de getrouwheid van het beeld.

Indien dit zo is, dan is de accountant op grond van zijn verklaring als zodanig voor niet meer verantwoordelijk dan dat hij elke fout die dit beeld zou aantasten, signaleert en het maakt hierbij geen verschil of het een slordigheid, een bewuste misleiding of een fraude betreft. In het voorgaande hoop ik te hebben aangetoond dat hij ook bij gebruik van steekproeven objectief gezien aan deze eis kan voldoen.

De indruk wordt wel eens gewekt, dat het maatschappelijk verkeer meer verwacht dan door de verklaring zelve wordt gerechtvaardigd, en met name dat de accountant fraude, ook al is deze onbetekenend ten opzichte van het beeld van de jaarrekening, zal ontdekken.

Indien aangenomen moet worden, dat deze meerdere verwachting bestaat, rijst hier een probleem. Indien de accountant aan deze verwachting niet voldoet dan bestaat de kans dat het vertrouwen in de accountant en daarmede het wezenskenmerk van de functie wordt aangetast. Persoonlijk geloof ik dat de gevaren hier meer theoretisch dan reëel zijn. De werkelijk ,verstandige" leek zal zich om geringe fraudes niet zo druk maken, zolang de gepubliceerde jaarrekeningen hem niet in de steek laten. Bovendien zou een dergelijk "meerder vertrouwen" economisch irrationeel zijn (zoals ik in het vervolg van dit artikel meer exact hoop aan te tonen). Toch zou het naar mijn mening aanbeveling verdienen het begrip van het maatschappelijk verkeer in deze door publicaties van N.I.V.A. resp. V.A.G.A. te verbeteren en de positie en de verantwoordelijkheid van de accountant scherper af te bakenen. Mogelijk kan de steekproeftheorie door zijn exacte formulering van de toleranties hierbij de helpende hand bieden.

\section{Is een meer objectieve bepaling van de omvang der te verrichten steekproeven mogelijk?}

Indien de steekproef als middel van accountantscontrole in principe wordt aanvaard, rijst de vraag welke grenzen de accountant bij zijn onderzoekingen moet stellen voor de twee elementen (tolerantie en toegelaten risico) die onverbrekelijk aan het waarnemen door middel van steekproeven verbonden zijn. De mathematische steekproef door zijn exacte berekening van tolerantie en risico geeft weliswaar reeds een meer objectieve grondslag an de bepaling van de controle-omvang, doch indien de waarden voor deze twee elementen subjectief worden bepaald, zou er in zekere zin sprake zijn van een verplaatsen van de moeilijkheid. Indien wij willen komen tot een bedrijfseconomisch verantwoorde controleomvang, zullen wij althans een poging moeten doen om te komen tot een tegen elkaar afwegen van nut en kosten.

Voor het analyseren van dit probleem is het noodzakelijk uit te gaan van een tweetal vóóronderstellingen ten aanzien van het nut van accountantscontrole enerzijds en van de wijze waarop risico's daarbij moeten worden gewaardeerd anderzijds. Ik geef hier eerst twee premissen, die door mij als uitgangspunt zijn gekozen: 
1. het ,nut" van het vinden van een fout bij de accountantscontrole is (maximaal) gelijk aan het bedrag van dic fout.

2. het risico van niet-ontdekking mag worden ingecalculeerd door vermenigvuldiging van dat risico met het bedrag waarover het risico wordt gelopen.

Met het eerste punt zal iedereen wel willen instemmen doch het twcede eist nadere overweging. Ik zou daartoe echter eerst de analyse nader willen uitwerken.

Op grond van de twee bovengenoemde premissen kan men de „waarde" van het risico, dat gelopen wordt door een deel der detailcontrole achterwege te laten (restrisico), indien men zich op een steekproefsgewijze controle baseert, als volgt uitdrukken: ,,(mogelijke) fout $\times$ risico van niet-ontdekking”.

De berekening van deze ,waarde” geschiedt door vermenigvuldiging van bij elkaar behorende waarden voor $\varepsilon$ en $\varphi$, zoals deze als voorbeeld zijn gegeven op pag. 463. De grootte van de fout is a priori niet bekend. Er doet zich echter de gelukkige omstandigheid voor dat het bovenaangegeven produkt, gegeven een bepaalde steekproefomvang, een maximum waarde heeft. Zoals in de appendix nader is aangetoond, wordt dit maximum bij een steekproefomvang (n) bereikt, indien de fout $=\frac{\mathrm{T}}{\mathrm{n}}$ (warin $\mathrm{T}=$ totaalbedrag van de postenreeks) bij welke fout het risico van niet-ontdekling gelijk wordt aan $\frac{1}{c}=0,368$. De maximumwaarde van de eerder gegeven vorm: ,(mogelijke) fout $X$ risico van niet-ontdekking" kan dus bij ecn steckproefomvang van n geschreven worden als

$$
\frac{1}{e} \times \frac{T}{n}=0,368 \frac{T}{n}
$$

We hebben thans een uitdrukking voor de maximumwaarde van het risico van niet-ontdekking voor een willekeurige steekproefomvang. De vraag die nu op grond van het economische motief gesteld moet worden is: Bij welke steekproefomvang zullen de kosten verbonden aan het verder uitbreiden van de controle gelijk zijn aan resp. groter worden dan de vermindering van de waarde van het „restrisico". Voor de bepaling van deze grens zij verwezen naar de appendix. Het blijkt, dat deze grens bereikt wordt bij de steekproefomvang

$$
\begin{aligned}
\mathrm{n} & =\sqrt{\frac{\mathrm{T}}{2,7183 \times \mathrm{k}}} \\
\text { waarin: } & \mathrm{T}=\text { totaalbedrag der te onderzoeken massa } \\
\mathrm{k} & =\text { controlekosten per te onderzoeken eenheid }
\end{aligned}
$$

Ter illustratic voor een en ander zijn in tabel II de gegevens weergegeven voor de controle van een totaalbedrag groot f 1.000.000,-, indien de controlekosten per post $\int 1,-$ bedragen. Voor dat geval volgt uit de formule, dat de steekproef moet worden beperkt tot 607 stuks. 


\begin{tabular}{|c|c|c|c|c|}
\hline \multirow{2}{*}{$\begin{array}{c}\text { Risico van } \\
\text { niet- } \\
\text { ontdekking }\end{array}$} & \multicolumn{2}{|c|}{$\begin{array}{l}\text { Bedrag van de fout, } \\
\text { waarbij het risico } \\
\text { van niet-ontdekking } \\
\text { is als aangegeven in } \\
\text { kolom } 1\end{array}$} & \multirow{2}{*}{$\begin{array}{l}\text { Vermindering } \\
\text { bedrag, waarover } \\
\text { risico wordt gelopen } \\
\text { (kolom } 2 \text { - kolom 3) }\end{array}$} & \multirow{2}{*}{$\begin{array}{l}\text { Kosten voortzetting } \\
\text { controle uitgedrukt } \\
\text { als percentage van } \\
\text { het bedrag in } \\
\text { kolom } 4\end{array}$} \\
\hline & $\begin{array}{l}\text { Bij steek- } \\
\text { proef } \\
\text { groot } \\
607 \\
\text { stuks }\end{array}$ & $\begin{array}{l}\text { Bij steek- } \\
\text { proef } \\
\text { groot } \\
617 \\
\text { stuks }\end{array}$ & & \\
\hline 1 & 2 & 3 & 4 & 5 \\
\hline 0,5 & $f \quad 1.150$ & 1.132 & $f \quad 18$ & $55 \%$ \\
\hline 0,368 & " 1.647 & 1.621 & ", 26 & $38 \quad 0 / 0$ \\
\hline 0,1 & ", 3.800 &,$\quad 3.725$ & " 75 & $13 \%$ \\
\hline 0,01 & , 7.570 & , 7.430 &, 140 & $7 \quad 0 \%$ \\
\hline 0,001 & $n 11.300$ &, 11.130 &, 170 & $6 \%$ \\
\hline 0,0001 & , 15.070 &, 14.800 & , 270 & $3,7 \%$ \\
\hline 0,00001 & , 18.790 & , 18.480 &, 310 & $3,2 \%$ \\
\hline 0,000001 & , 22.510 &, 22.140 & , 370 & $2,7 \%$ \\
\hline
\end{tabular}

Uit kolom 4 blijkt het bedrag, waarmede de fout, corresponderend met elk in kolom 1 aangegeven risico-niveau, daalt door uitbreiding van de steekproef van 607 naar 617 stuks. De kosten van deze uitbreiding bedragen in het gegeven cijfervoorbeeld $f 10$, - en deze kosten zijn als ,premiepercentage" van het „,verzekerd belang" (kolom 4 ) in kolom 5 uitgedrukt.

Op dit punt is het wellicht nuttig in te gaan op de tweede premisse, dat het risico van niet-ontdekking mag worden ingecalculeerd door vermenigvuldiging daarvan met het bedrag waarover dat risico wordt gelopen. Het is duidelijk, dat door de controlekosten tegen deze waarde af te meten, de daardoor uitgespaarde controlekosten gemiddeld juist opwegen tegen de schade door niet-ontdekking. M.a.w. in een voldoend groot aantal controle-gevallen zullen de bespaarde controle-kosten gelijk zijn aan de totale schade. Dit geldt echter in tweeërlei opzicht slechts op één punt, namelijk indien

(a) de eventuele fout juist zodanig is dat het risico van niet-ontdekking ongeveer $37 \%$ is. In alle andere gevallen komt het controlekostenpercentage (kolom 5) er veel ongunstiger af dan het risico (kolom 1 ).

(b) De gelijkstelling geldt slechts voor de eerste uitbreiding boven 607 stuks. Elke volgende uitbreiding geeft een steeds ongunstiger beeld. Zo geeft bijvoorbeeld een uitbreiding van de steekproef met 300 stuks een percentage te zien van $55 \%$ bij een risico van $0,368 \%$.

Gegeven het bovenstaande en gelet op het feit dat het „premiepercentage” 
zeer hoog is zolang van een reëel risico gesproken moet worden, blijft er bij mij geen twijfel over dat op dit punt het risico lopen een betere keuze is dan voortzetting der controle.

\section{Verband tussen steekproefomvang en interne organisatie en controle}

In het voorgaande is uiteengezet hoe op grond van het economisch motief een maximum steekproefomvang kan worden aangegeven. Daarbij is, zoals reeds opgemerkt, nog geen rekening gehouden met het feit dat fouten (althans diegene die het bedrijf benadelen) wellicht nagenoeg of in het geheel niet voorkomen. Ik meen dat wij de eerder gegeven uitdrukking voor de waarde van het restrisico mogen aanvullen en weergeven als het gedurig produkt van:

(i) kans dat fout voorkomt

(ii) (mogelijke) fout

(iii) risico van niet-ontdekking.

(Deze gedachte is, zij het in andere vorm, ook te vinden in de colleges van Prof. R. W. Starreveld)

Stellen wij de eerste factor voor door c (waarbij c een getal is tussen 0 en 1), dan kan de eerder gegeven formule voor de maximumwaarde van het restrisico als volgt worden geschreven

$$
\mathrm{c} \times \frac{\mathrm{T}}{\mathrm{n}}-\times \frac{1}{\mathrm{e}}
$$

De formule voor de maximale steekproefomvang wordt dan

$$
\mathrm{n}=\sqrt{\frac{\mathrm{c} \times \mathrm{T}}{2,7183 \times \mathrm{k}}} \text { (zie appendix) }
$$

Het is in de praktijk uiteraard niet mogelijk voor c een exacte waarde aan te geven, doch wel weten wij zowel uit theoretische overwegingen als uit praktische ervaring dat deze factor $c$ kleiner is naarmate de interne organisatie en controle beter zijn verzorgd.

Maar dan volgt uit de formule dat ook de steekproefomvang kleiner moet zijn, naarmate dit het geval is. Hiermede hoop ik een theoretische fundering te hebben gegeven voor een stelling die al vele malen intuïtief is uitgesproken, waarbij ik in mijn betoog de „klassieke” gedachte van een greep op het totaalbedrag door eigen actie meen te hebben gehandhaafd. Hierin zou de overbrugging kunnen liggen van de tegenstelling tussen ,klassiek" en ,modern”.

De vraag rijst nog of de factor c zo klein kan worden, dat detailcontrole als onderdeel van de accountantsarbeid geheel achterwege kan worden gelaten. In het kader van dit artikel zou ik dit punt echter niet verder willen uitwerken.

\section{Het aantreffen van een fout in de steekproef}

$\mathrm{Bij}$ de hiervoor beschreven methode is er (evenals door De Wolff) van uitgegaan dat in de verrichte steekproeven geen fout wordt aangetroffen. De vraag rijst dan, wat gedaan moet worden indien dit wel het geval zou zijn.

In de eerste plaats zou ik willen verwijzen naar hetgeen eerder in dit artikel 
onder 4 is gezegd over hetgeen als fout moet worden aangemerkt. Bij de aangegeven steekproefmethode is de kans een fout in de steekproef aan te treffen dus aanzienlijk gereduceerd.

Naast de meest ernstige soort fout, als hoedanig ik het niet gedekt zijn van een post zou willen betitelen, zijn fouten van „lager orde" denkbaar (bijv. klassificatiefouten of het ontbreken van voorgeschreven parafen). Voor deze fouten van lager orde kan men ruimere toleranties stellen, zodat ten aanzien van dit soort fouten één of meer in de steekproef aangetroffen gevallen de vooropgestelde betrouwbaarheidseisen onaangetast laten. Er zijn tabellen beschikbaar, waaruit voor verschillende steekproefaantallen en verschillende aantallen in de steekproef aangetroffen ongunstige gevallen het betrouwbaarheidsniveau van de waarneming kan worden afgelezen. Ook dit betekent een vermindering van de kans op een onbevredigende steekproefuitkomst.

Tenslotte wordt nog uitkomst geboden door de methode van "sequential sampling", welke methode de mogelijkheid opent om een in eerste instantie niet bevredigend resultaat door aanvullende steekproefseries alsnog tot een bevredigend resultaat om te buigen. Eerder is in dit maandblad een beschrijving van deze methode opgenomen in de publicatie van Louwers 4). Er moet wel op worden gewezen dat bij toepassing van deze methode de eerste steekproefserie groter moet worden genomen dan volgens de in dit artikel aangegeven formule.

\section{Slot}

In het voorgaande is getracht een voor accountantscontrole geschikte steekproefmethode te introduceren. Voorts is een poging gedaan de problematiek, die aan het gebruik van steekproeven is verbonden, wat dieper te analyseren. Daarbij is wellicht de nadruk sterk gelegd op de wiskundige benadering. Ik meen echter dat het steekproefprobleem niet vruchtbaar kan worden onderzocht zonder de wiskundige aspecten ten volle in de discussie te betrekken. Noodgedwongen is daardoor het probleem gesimplificeerd. Ongetwijfeld zullen vragen rijzen, die in bepaalde gevallen tot gedeeltelijke herziening of verfijning van de analyse aanleiding kunnen geven. Voorts is deze beschouwing ook in dien zin gesimplificeerd, dat het probleem is toegespitst op de positieve detailcontrole. Ik meen echter dat toepassing van de guldenrangnummermethode, die in zekere zin te vergelijken is met de z.g. multimomentopname, ook in andere opzichten interessante mogelijkheden biedt. Slechts als voorbeeld zou ik willen noemen een statistische marge-beoordeling in gevallen waarin een veelheid van artikelen en/of soorten afnemers tot een grote variatie in winstopslag leidt. Het storende element van de varierende postgrootte en een zekere correlatie die vaak bestaat tussen postgrootte en winstopslag kan door toepassing van de guldenrangnummermethode worden geëlimineerd.

\section{Literatuurlijst}

1. Kleerekoper, S., De steekproeven als middel van accountantscontrole in de literatuur. M.A.B. februari/juni 1933

2. Wolff, P. de, Steekproeven bij administratieve controle. Statistica Neerlandica 1956 nr. 1 
3. Cohen, H., Een ten behoeve van de administratieve controle ontworpen steekproefmethode. M.A.B. januari 1958

4. Louwers, P. C., De steekproef in de accountantscontrole. M.A.B. juni 1958/ juni 1959

5. Goudeket, A., De steekproef in de accountantscontrole. M.A.B. Limpergnummer 1959

6. Meij, H., De toepassing van steekproeven door de accountant. M.A.B. februari 1960

7. Wolff, P. de, Produktiviteitsverhoging bij accountantscontrole door toepassing van gelaagde steekproeven. Statistica Neerlandica 1959 nr. 2

8. Meij, A., Retrospectieve steekproeven in het controleprogramma van de public-accountant. M.A.B. september 1961 


\section{Stratificatie-methode}

Volgens het gegeven voorschrift wordt in iedere grootte-klasse (bovensgrens $P_{i}$ ) een fractie gecontroleerd, welke fractie wordt bepaald door de volgende formule:

$$
1-\left(1-\frac{P_{i}}{T}\right) \frac{\ln \varepsilon}{\ln (1-\varphi)}
$$

Te bewijzen is, dat indien in de aldus onderzochte posten geen fout wordt aangetroffen, de uitspraak kan worden gedaan dat behoudens een kans $\varepsilon$ op het tegendeel, de som van alle foute posten een fractie $\varphi$ van het totaalbedrag van de gehele massa ( $T$ ) niet overschrijdt.

Het bewijs is geleverd indien aangetoond kan worden, dat het voorschrift slechts een kans $\mathbf{a}=\varepsilon$ oplevert om uitsluitend goede posten te treffen, zodra de som van alle foute posten gelijk is aan $\varphi \mathrm{T}$.

De voorkomende foute posten kunnen in de meest algemene vorm worden geschreven als:

$$
\mathrm{P}_{\mathrm{i}_{1}}+\mathrm{P}_{\mathrm{i}_{2}} \ldots \ldots+\mathrm{P}_{\mathrm{i}_{\mathbf{k}}}=\varphi \mathrm{T}
$$

De kans een bepaalde foute post te treffen is gelijk aan de in die grootte-klasse te onderzoeken fractie en dus volgens het voorschrift:

$$
1-\left(1-\frac{P_{i}}{T}\right) \frac{\ln \varepsilon}{\ln (1-\varphi)}
$$

(Wij zien hier af van het geval dat de foute post kleiner is dan de bovengrens van de grootte-klasse. In dat geval is de trefkans groter en derhalve de kans op een onjuiste uitspraak kleiner.)

De kans een bepaalde foute post niet te treffen is het complement en dus

$$
\left(1-\frac{P_{i}}{T}\right)^{\frac{\ln \varepsilon}{\ln (1-\varphi)}}
$$

De kans a geen der foute posten te treffen wordt dan

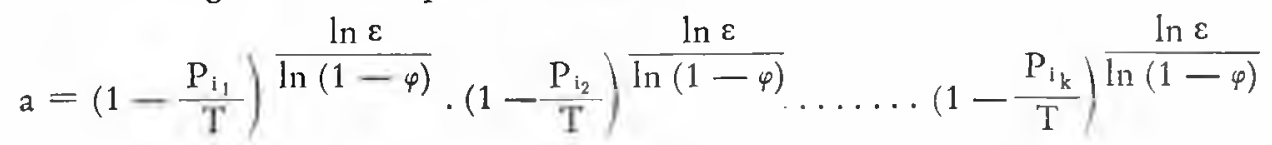
Aangezien $\frac{P_{i}}{T}$ steeds een zeer kleine fractie van 1 is, geldt in goede benadering:

$$
\begin{aligned}
& x=e^{-\frac{P_{i_{1}}}{T} \frac{\ln \varepsilon}{\ln (1-\varphi)}} \cdot e^{-\frac{P_{i_{2}}}{T} \frac{\ln \varepsilon}{\ln (1-\varphi)} \ldots \ldots e^{-}} \ldots \frac{P_{i_{1}}}{T} \frac{\ln \varepsilon}{\ln (1-\varphi)} \\
& =e^{-}-\frac{\ln \varepsilon}{\ln (1-\varphi)} \cdot \Sigma \frac{P_{i}}{T} \\
& \operatorname{met} \Sigma \frac{P_{i}}{T}=\varphi \operatorname{en} \ln (1-\varphi) \sim-\varphi(\varphi<<1)
\end{aligned}
$$

volgt hieruit

$$
a=e^{\ln \varepsilon}-\varepsilon \text { (hetgeen te bewijzen was) }
$$


II. Maximumwaarde fout $\times$ risico

Stel: steekproefomvang $=\mathrm{n}$

totaalbedrag der te

onderzoeken massa $=\mathrm{T}$

fractie foute guldens $=\varphi$

Het risico, dat in de steekproef van n guldens niet één der foute guldens voorkomt is

$$
(1-\varphi)^{\mathrm{n}}
$$

en het produkt $A$ van fout $X$ risico kan dus worden geschreven als:

$$
\mathrm{A}=\varphi \mathrm{T}(1-\varphi)^{\mathrm{n}}
$$

Voor gegeven $n$ wordt een extreme waarde bereikt wanneer:

$$
\text { of } \begin{aligned}
\frac{\mathrm{dA}}{\mathrm{d} \varphi} & =(1-\varphi)^{\mathrm{n}} \mathrm{T}-\mathrm{n} \varphi \mathrm{T}(1-\varphi)^{\mathrm{n}-1} \\
& =(1-\varphi)^{\mathrm{n}-1} \mathrm{~T}(1-\varphi-\mathrm{n} \varphi)=0 \\
\varphi & =\frac{1}{\mathrm{n}+1}
\end{aligned}
$$

Gemakkelijk valt in te zien, dat de tweede afgeleide

$$
\frac{\mathrm{d}^{2} \mathrm{~A}}{\mathrm{~d} \varphi^{2}} \text { voor } \varphi=\frac{1}{\mathrm{n}+1}
$$

negatief is, zodat de waarde van A maximaal is voor

$$
\varphi=\frac{1}{\mathrm{n}+1} \propto \frac{1}{\mathrm{n}}
$$

Substitutie in (1) geeft met $\quad\left(1-\frac{1}{n}\right)^{n} \approx \frac{1}{e}$

$$
\mathrm{A}_{\max }=\frac{\mathrm{T}}{\mathrm{en}}
$$

III. Economische grens der controle-omvang

De annotatie onder II wordt aangehouden, terwijl de controlekosten per te onderzoeken post worden voorgesteld door $k$.

De vraag is nu bij welke waarde van $\mathbf{n}$ de kosten van voortzetting der controle hoger zijn dan de daardoor bereikte vermindering van de waarde van het „restrisico":

$$
\mathrm{A}_{\max }=\frac{\mathrm{T}}{\mathrm{en}}
$$

De totale controlekosten kunnen worden voorgesteld door nk en de vraag wordt dan, bij welke waarde van $n$ de vorm $\frac{T}{\mathrm{en}}$ minder daalt dan nk stijgt indien wij n laten toenemen. 
Differentiatie van beide vormen naar $n$ en gelijkstelling levert op

$$
\frac{T}{e n^{2}}=k
$$

zodat de gevraagde waarde van $n$ wordt gevonden als

$$
\begin{aligned}
\mathrm{n} & =\sqrt{\frac{\mathrm{T}}{\mathrm{ek}}} \\
& =\sqrt{\frac{\mathrm{T}}{2,718 \mathrm{k}}}
\end{aligned}
$$

IV. Economische grens der controle-omvang, indien rekening wordt gehouden met de kans dat fouten voorkomen

Zij de kans dat fouten voorkomen c. Deze kans wordt bepaald door de sterkte der interne organisatie en controle, is echter onafhankelijk van de omvang der externe controle ( $\mathrm{n})$.

Overeenkomstig het gestelde in paragraaf 12 is de waarde van het restrisico in dat geval

$$
\frac{\mathrm{cT}}{\mathrm{en}}
$$

Dit gesteld tegenover de controlekosten $n \times k$ geeft nu als economische grens der controle-omvang:

$$
\mathrm{n}=\sqrt{\frac{\mathrm{cT}}{2,718 \mathrm{k}}}
$$

